\title{
A new Middle Miocene mammalian fauna from Mordoğan (Western Turkey)
}

\author{
TANJU KAYA, Izmir, DEnis GeraAds, Paris \& VAhDET TunA, Izmir *
}

With 6 figures

Zusammenfassung: Ardiç-Mordogan ist ein neue Fundstelle in die Karaburun Halbinsel von Westtürkei. Unter ihre Fauna, das ist hier beschreibt, sind die Carnivoren besonders interessant, mit die vollständigste bekannten Exemplaren von Percrocuta miocenica und von eine primitiv Hyänen-Art, von welche ein neue Unterart, Protictitherium intermedium paralium, beschreibt ist. Die Fauna stark gleicht die von mehrere anderen Mittelmiozän Lagerstatten in derselben Gebiet: Çandir, Paşalar und Inönü in Türkei, und Prebreza in Serbien, und sie mussen sich allen zu dieselben Mammal-Zone gehören. Seinen Huftieren bezeugen ein offenes Umwelt, das bei der Türko-Balkanisch Gebiet in Serravallien Zeit verbreiten mussten.

Abstract: Ardiç-Mordogan is a new fossil Mammal locality in the Karaburun Peninsula of Western Turkey. Among its fauna, which is described here, the carnivores are especially interesting, with the most complete specimens ever found of Percrocuta miocenica and of a primitive species of hyaenid, of which a new subspecies is described, Protictitherium intermedium paralium. This fauna is strongly reminiscent of those of several other Middle Miocene localities in this area, Çandir, Paşalar and Inönü in Turkey, and Prebreza in Serbia, and they must all belong to the same mammalian zone. Their ungulates attest an open environment which must have been widespread in the Turko-Balkanic area in Serravallian times.

\section{Introduction}

At the cross-roads between continents, Turkey played a central role in the evolution of Mammalian faunas. Its importance is further enhanced, in the Miocene, by its exceptional richness in Hominoids, with at least 4 different taxa belonging to several lineages.

\footnotetext{
* Adresses of the authors: TANJU KAYA \& VAHDET TUNA, Ege Universitesi - Tabiat Tarihi Muzesi, P.K.38, 35100 Bornova-Izmir, Turkey, e-mail tanju@sci.ege.edu.tr ; DENIS GERAADS, CNRS UPR 2147, 44 rue de l'Amiral Mouchez, 75014 Paris, France, e-mail dgeraads@ivry.cnrs.fr
} 
Unravelling their relationships can hardly be done without knowledge of their relative ages. However, large Mammal biochronology of this period is still poorly understood, perhaps because, too often, dubious correlations have been attempted between Turkish and European sites, instead of focusing first on the Turkish succession. In this regard, we hope that the new fauna described here will be a useful contribution to the biochronology of this area.

Measurements are in mm. Upper teeth are in upper case, lower teeth in lower case. Fossils from Mordogan are kept in the Tabiat Tarihi Muzesi (Natural History Museum), Ege Universitesi, Izmir, Turkey, and numbered IMA (for Izmir-Mordoğan-Ardiç). MTA stands for Maden Tetkik ve Arama Enstitusu, Ankara.

\section{Geological setting}

The pre-Neogene basement in the Karaburun Peninsula consists of a Lower Triassic (ERDOĞAN et al. 1990) or Palaeozoic (ROBERTSON \& PICKETT 2000) clastic assemblage, a middle Triassic to Jurassic carbonate assemblage, and an upper unconformably overlying Late Cretaceous to Paleocene "Bornova Mélange" (ERDOĞAN et al. 1990; RoBERTSON \& PICKETT 2000). In outlines, the basement succession is known to be comparable with that on Chios island just off the Karaburun Peninsula.

On the Karaburun Peninsula, the Neogene sedimentary strata (Fig.1a) are primarily confined to the eastern shoreline, and overlie a volcanic succession terminating with a felsic tuff unit. There are only a few previous reports of mammalian faunas in the area. A small fauna has been reported from Çiftlikköy near Çesme (BESENECKER 1973). It consists of Gomphotherium sp., Sanitherium leobense and Ruminantia indet, and indicates a Middle Miocene age. In the north, near the locality of Karaburun, an unpublished Late Miocene mammalian fauna from the upper unit is probably roughly equivalent in age with the classic locality of Pikermi in Greece.

The Ardiç formation, deposited by a fluvial system, consists of brown-gray, thick to massively bedded lithic to volcanoclastic sandstone and conglomerate (Fig.1b). The unit exhibits a general fining-upwards, and contains calcareous mudrock intercalations at the top. It rests unconformably on the Foça tuff.

Near Mordoğan, the uppermost part of the Ardiç formation yielded a Middle Miocene fauna at the locality Ardiç (N 38³1'42.3" ; E 28³7'30"). It was discovered by NESET ÖZTEKIN in 1997, and has been subject to small-scale excavations since then. The fossiliferous layer is exposed in a steep cliff about $20 \mathrm{~m}$ above the sea, but the site is too dangerous for large excavations to be conducted. However, the collection already includes 
some well preserved specimens, and the mammalian fauna as a whole is complete enough to make Mordoğan a new reference locality in the Eastern Mediterranean Middle Miocene.

\title{
Systematic description
}

\author{
Order Carnivora
}

Family Mustelidae

Genus Ischyrictis HeLBING, 1930

Type species. Ischyrictis zibethoides (BLAINVILLE, 1841)

Ischyrictis cf. anatolicus SCHMIDT-KITTLER, 1976

A fragment of mandible (IMA-12) bears only the posterior part of m1, but also shows the alveolus of a rather large, single-rooted $\mathrm{m} 2$. There was no $\mathrm{m} 3$. On $\mathrm{m} 1$ (width = ca. 7), the tip of the protoconid is broken off, but a very small metaconid, closely pressed against the latter cuspid, is visible. The talonid is short, and bears a single trenchant cuspid.

In spite of its fragmentary condition, this specimen so closely resembles the large mustelid Ischyrictis anatolicus from Çandir (type-locality; SCHMIDT-KITTLER 1976; NAGEL in press), Paşalar (VIRANTA \& ANDREWs 1995) and Belometchetskaya (PICKFORD et al. 2000), that generic, if not specific, identity is likely. The genus Ischyrictis itself has a broader geographic and chronological range, being known from Spain to Turkey, from the late Early Miocene until the early Late Miocene, but I. anatolicus seems to be restricted to sites of early Middle Miocene age.

\section{Carnivora indet.}

A fragment of mandible with p2 and p3 looks also mustelid, but is too large (p2 = 9 $\mathrm{x} 5.1 ; \mathrm{p} 3=11.2 \times 5.5$ ) to belong to the previous species, and the premolars are less crowded.

Family Percrocutidae

Genus Percrocuta KRETZOI, 1938

Type species. Percrocuta carnifex (PILGRIM, 1913)

Percrocuta miocenica PAVlovic \& ThenIUS, 1965

Description. The best fossils from Ardiç-Mordoğan are an associated set of a maxilla and a mandible bearing P2-P4 and p2-m1, IMA-3. All teeth are well-preserved, although well worn (Figure 2, A-D).

Measurements: 
Upper teeth: $\mathrm{P} 2=15.3 \times 10.6 ; \mathrm{P} 3=20.8 \times 12.4 ; \mathrm{P} 4=32.8 \times-$; length $\mathrm{P} 2-\mathrm{P} 4=69$

Lower teeth: canine $=14.6 \times 11.7 ; \mathrm{p} 2=13.1 \times 9.6 ; \mathrm{p} 3=16.5 \times 10.8 ; \mathrm{p} 4=19.3 \times 11.2$; $\mathrm{m} 1=23.8 \times 11.2$, trigonid length $=20.8 ;$ length $\mathrm{p} 2-\mathrm{m} 1=69.8$

Other measurements are : Length from orbit to $\mathrm{P} 4=43.5$; Width over external sides of lower canines $=43.7$

The maxilla is preserved up to the lower border of the orbit; its anterior border is not preserved, but it certainly reached at least the level of the middle of $\mathrm{P} 3$, confirming the observation of WERDELIN \& SOLOUNIAS (1991) that the orbit is more anterior in this genus than in the Hyaenidae.

It is impossible to tell whether a P1 was present. The P2 differs from those of Çandir and Paşalar illustrated by SCHMIDT-KITTLER (1976, fig. 46-47) by its slightly different outline, the disto-lingual corner being here more nearly a right angle. The tooth is not much broader posteriorly than anteriorly, but is definitely more rectangular than the specimen from Al Jadidah (Howell \& PetTer 1985, pl. 2, fig. 2). The P3 has only a weak mesio-lingual vertical ridge. It lacks a lingual third root such as found at Al Jadidah, but is also narrower than teeth lacking this root, from Paşalar, Çandir, and P. carnifex from India, and even relatively narrower than the smaller P. abessalomi from Belometchetskaya (measurements in Howell \& PetTer 1985). P4 is much worn lingually, but it can still be seen that the protocone occupied an anterior position, its mesial border being almost as anterior as that of the parastyle, as in the Al Jadidah and Pasalar specimens (HowELL \& PETTER 1985: 433). A single minute alveolus is the only evidence of a much reduced M1.

Like its upper counterpart, the third lower premolar has almost no anterior cuspid. Thus, it resembles more the specimens from Paşalar (SCHMIDT-KITTLER 1976: 51, fig. 44) and Inönü (unpubl. spec. 2394 in MTA, Ankara) than those of Prebreza (PAVLOVIC 1969, pl. 3-5; Howell \& PetTer 1985, pl. 1, fig. 4) in which this cuspid is stronger. This is, however, a variable feature in hyaenoids. The $\mathrm{p} 4$ does not significantly differ from other specimens of early Percrocuta. The lower carnassial has no metaconid, and a short talonid.

Simpson's diagram of tooth proportions of Middle Miocene Percrocuta shows (Fig. 3) that P. tobieni from Kenya (CRUSAFONT \& AGUIRRE 1971) is certainly distinct, that P. carnifex from India (measurements in Howell \& PETTER 1985) is also distinct by its short carnassial and broad premolars, and that one of the specimens from Tung Gur in Mongolia (AM 26598, which is the most similar to the Eastern Mediterranean examples) also has very broad teeth (although included in P. tungurensis by COLBERT 1939, it is certainly distinct from this species, as already noted by several authors). It is less easy to distinguish between the other samples. P. abessalomi from Belometchetskaya (GABUNIA 
1973; Howell \& PETTER 1985) is the smallest and has narrow teeth and relatively short $\mathrm{p} 4$, all primitive features, and could be the ancestral form, despite the posterior position of the protocone on the upper carnassial.

All other samples are closely similar (that of Çandir consists of two isolated teeth only), and it would be unwise to draw biochronological conclusions from the small size differences between them.

A fragment of mandible with the alveoli of the canine and p2, IMA-45, should also be referred to the same taxon.

Family Hyaenidae

Genus Protictitherium KRETZOI, 1938

Type species. Protictitherium crassum (DEPÉRET, 1892)

Protictitherium intermedium SCHMIDT-KITTLER, 1976

Protictitherium intermedium paralium n.ssp.

Holotype. IMA-42, right mandible with well-preserved unworn p3-m2. Housed in the Natural History Museum of the Ege University, Izmir, Turkey (Fig. 4).

Diagnosis. A subspecies of $P$. intermedium similar in size to the nominal subspecies, from Çandir and Paşalar, but premolars with higher main cusps, and entoconid of $\mathrm{m} 1$ higher and more anterior.

Measurements. p3 $6.2 \times 2.7 ; \mathrm{p} 4: 7.1 \times 3.4 ; \mathrm{m} 1=9.2 \times 4.2 ; \mathrm{m} 2: 4.4 \times 3.3$

Derivatio nominis. from Greek paralia, beach, which is just below the type-locality.

Description. The type mandible is the most complete specimen known of this species, which is of small size (Fig. 5). It is broken in front of p3. The latter tooth consists of a high and trenchant main cusp, with only a slight notch at mid-height of its posterior edge, a very small anterior accessory cuspid, and a weak posterior cingulum. The p4 is felinoid, with an anterior cuspid larger than that of p3, but still small, a high lanceolate main cusp, and a very strong posterior cuspid, circled by a strong cingular bur, which continues along the whole labial side. On the carnassial, the trigonid is only slightly longer than the talonid. The protoconid is much higher than the paraconid, which is very slightly higher than the metaconid. The entoconid is clearly higher and more anterior than the hypoconid, while it is only slightly higher, or of the same height, and more posterior, at Çandir (SCHMIDTKITTLER 1976 ; NAgel in press). A high entoconid on $\mathrm{m} 1$ is also found in Protictitherium cf. gaillardi from Paşalar (SCHMIDT-KITTLER 1976), but it is much more posterior, and the talonid is much longer in this species. The $\mathrm{m} 2$ from Mordoğan does not differ significantly from those of Çandir. 
The differences between the Mordoğan and Çandir specimens are not great, but they point to a more derived condition in the former site, that should be taxonomically acknowledged.

\section{Order Proboscidea}

Family Amebelodontidae

Genus indet., cf. Protanancus Arambourg, 1945

Type species. Protanancus macinnesi ArAmBOURG, 1945

\section{cf. Protanancus sp.}

A few proboscidean teeth cannot be definitely identified. There is no evidence that they belong to more than one taxon.

IMA-41 (Fig.2 E) is the tip of a right lower incisor, about $40 \mathrm{~mm}$ long. It is unworn, and completely covered with enamel, itself covered by a thin layer of cement, except at the very tip. It is extremely dorso-ventrally flattened, (medio-lateral $=26$; dorso-ventral $=$ 9.0 ), the lateral part more so than the medial one. The ventral part is more or less flat, the lateral part of the dorsal side is gently concave. This incisor looks much like that of Archaeobelodon filholi (TASSY 1987, fig. 15), but it is more compressed, at least as much as those of Protanancus (TASSY 1986, fig. 19), Amebelodon or Platybelodon (GAZIRY 1976, pl. 3). The dentine is tubular in the latter genus, while it is lamellar in the other two; unfortunately, it is not preserved in the Mordoğan specimen.

Anterior cheek teeth are imperfectly known in the above-mentioned genera. Three of them were found in Mordoğan. Their wrinkled enamel and incipient supernumerary cusps suggest affinities with the Amebelodontidae and Choerolophodon, two taxa known in the area at that time. However, although they probably do not permit a generic identification, several of their features set them apart from the latter genus: - a small tooth (IMA-23; measurements : 24.5 x 17.3) differs from the dp2 of Choerolophodon (GAZIRY 1976; TASSY 1983) by its outline which is more ovoid than triangular, and its weak anterior cingulum. Thus, it must belong to another taxon, because other teeth of similar size and morphology (dp2 and premolars) are lost in Choerolophodon.

- an imperfectly preserved dp3 (IMA-52; measurements : 37.5 x 22.5) looks like those of Choerolophodon by the widening of the posterior lobe, and the blocking of the transverse valley, but the pretrite central conule is connected to the protoconid, whereas it is shifted between the metaconid and hypoconid in Choerolophodon (TASSY 1986: 70). 
- on dp4 (IMA-51, Fig. 2 F; estimated length : 60 ), although the pretrite part of the second lophid is distinctly shifted posteriorly, and the central conules are strong, as in Choerolophodon, the anterior cingulum is moderate, and the mesoconelets of the first lophid are small and lower than the main tubercles, in contrast to this genus.

Of course, the features of these teeth (and even the presence of a lower incisor) could fit a Choerolophodon more primitive than all known species, but on the whole they agree better with those of the Amebelodontidae, a family which has already been reported from the Middle Miocene of this area at Arapli and Yürükali (GAZIRY 1976) and, doubtfully, at Çandir (GERAADS \& GÜLEÇ in press).

\section{Order Perissodactyla \\ Family Rhinocerotidae}

Genus Beliajevina HeIssig, 1974

Type species. Beliajevina tekkayai HeISSIG, 1974

\section{Beliajevina sp.}

A few tooth fragments belong to an "Hispanotheriinae" (this sub-family might not be monophyletic). It is probably the same as that found in other Middle Miocene Turkish sites.

\section{Order Artiodactyla \\ Family Suidae}

Genus Listriodon VON MEYER, 1846

Type species. Listriodon splendens VON MEYER, 1846

\section{Listriodon splendens VON MEYER, 1846}

IMA-28 is a left $\mathrm{m} 1$, fully lophodont, whose size falls near the middle of the range from both Paşalar and Çandir:

$\begin{array}{lccc} & \text { Mordoğan } & \text { Paşalar } & \text { Çandir }\left({ }^{3}\right) \\ \text { Maximum length } & 18.7 & \text { c. } 17.3-20.2\left(^{1}\right) & 16.2-20.9 \\ \text { Maximum width } & 14.6 & 11.9-15.2\left({ }^{2}\right) & 13.2-14.9 \\ & & \\ \left({ }^{1}\right) \text { VAN DER MADE 1996, fig. 51; }\left(^{2}\right) \text { FORTELIUS \& BERNOR 1990; }\left({ }^{3}\right) \text { VAN DER MADE in } \\ \text { press. }\end{array}$

A fragment of canine, IMA-19, probably also belongs to this genus. 


\section{Family Giraffidae}

Genus Giraffokeryx PILGRIM, 1910

Type species. Giraffokeryx punjabiensis PILGRIM, 1910

\section{Giraffokeryx sp.}

Two incomplete Giraffid m3s (IMA-26 and IMA-27) are of the size and morphology of specimens referred to this genus, which probably includes more than one species in the Eastern Mediterranean. They have no ectostylids, lateral lobes are rather Vshaped in occlusal view, and they are not very brachyodont. One of them, well worn, has a third lobe consisting of a single tubercle, while it forms a complete loop in the other specimen, as in all Paşalar and Çandir m3s of Giraffokeryx, and in Georgiomeryx from Chios (BonIs et al. 1997). At Prebreza, however, the third lobe of $\mathrm{m} 3$ is sometimes simple (PAVLOVIC 1969). The available material from Ardiç-Mordoğan is too scanty for a specific identification.

Family indet.

Genus Micromeryx LARTET, 1851

Type species. Micromeryx flourensianus LARTET, 1851

Micromeryx sp.

An incomplete radius and a distal metacarpal (distal width $=13.2$; width of shaft $=$ 7.4) of a very small ruminant match the size of this genus, present in most Middle Miocene Eastern Mediterranean sites. All other ruminants of this period are significantly larger, and Micromeryx can confidently be included in the Ardiç-Mordoğan faunal list.

\section{Family Bovidae}

Genus Turcocerus KÖHLER, 1987 ?

Type species. Turcocerus grangeri (PILGRIM, 1934)

Turcocerus sp. ?

IMA-8 is a small astragalus whose size (medial height $=23.5 ;$ distal width $=15)$ corresponds to that of the Turcocerus gracilis from Çandir (GERAADS, in press; Fig. 6). We tentatively refer it to this genus, also known in Mongolia and China, but not in Europe.

Genus Tethytragus AZANZA \& MORALES, $1994 ?$

Type species. Tethytragus langai AZANZA \& MORALES, 1994

Tethytragus sp. ? 
A mandible with much worn teeth, IMA-20, display no clear difference from Tethytragus koehlerae of Çandir, but is larger (length $\mathrm{m} 1-\mathrm{m} 3=50.1$, instead of $35.6-46.0$ for 100 Çandir specimens [GERAADS in press]). However, two astragali plot among those of Tethytragus koehlerae from Çandir (Fig. 6). Referral of these specimens to Tethytragus is very tentative, because no diagnostic feature is visible, and because of the difference in size of the mandible, but there is no other likely identification in the Middle Miocene of this area.

Genus Hypsodontus SoKOLOv, 1949

Type species. Hypsodontus miocenicus SOKOLOV, 1949

Hypsodontus pronaticornis KÖHLER, 1987

Three horn-cores (IMA-1, IMA-2 and IMA-34), still attached to fragments of frontal bones, display the typical morphology of Hypsodontus pronaticornis (Fig. $2 \mathrm{G}$ ). They have an almost circular cross-section, the right horn-core has a clockwise torsion, the horn-cores are almost parallel at the base, divergent higher up, but the tips re-approach and were certainly close to each other. The dimensions of the best specimen are: basal index $=$ $33.2 \times 31.4$; length along anterior curve $=c .200$. These basal horn-core measurements plot among those of Çandir; they are smaller than at Inönü (GERAADS et al. 1995). The frontal is flat between the horn-cores, and hollowed by extensive sinuses. The supra-orbital canal is directed backwards from the supra-orbital foramen to the orbit. The post-cornual fossa is large but shallow.

Most of the bovid teeth also belong to Hypsodontus. They are characterised by their large size, hypsodonty, flat posttrite walls and narrow prominent styles. The lengths at mid-height of $3 \mathrm{~m} 3 \mathrm{~s}$ are $33.8,32.7$ and $31.5 \mathrm{~mm}$; these values are quite similar to those of Çandir.

Finally, three astragali plot among those of H. pronaticornis from Çandir (Fig. 6).

\section{Conclusions}

The fauna of Ardiç-Mordogan includes at least 11 species. As we have seen, some of the identifications are better supported than others, and further discoveries may refine them. The present list is as follows:

Ischyrictis cf. anatolicus SCHMIDT-KITTLER, 1976; Carnivora indet.; Percrocuta miocenica PAVlovic \& ThenIUS, 1965; Protictitherium intermedium paralium n.ssp.; cf. Protanancus sp.; Beliajevina sp.; Listriodon splendens VON MEYER,1846; Giraffokeryx 
sp.; Micromeryx sp.; Turcocerus sp. ?; Tethytragus sp. ?; Hypsodontus pronaticornis KÖHLER, 1987.

Environment. Almost all these species or genera are present in Çandir (GERAADS et al. in press), and most of them are also present in Paşalar and Inönü, two sites which are respectively, in our opinion, earlier and later than Çandir. At Mordoğan, the most common ungulate is the bovid Hypsodontus, a specialized grazer, quite derived in its chewing apparatus. Other ungulates, cf. Turcocerus, cf. Tethytragus, and even the small Micromeryx, as well as the rhino, were probably also mostly grazers, being all rather hypsodont for their geological age. This shows that the open environment previously documented at Çandir (GERAADS et al. in press) was in fact widespread in the Western part of Turkey.

Biochronology. The absence of Turcocerus and Protictitherium at Paşalar would suggest that Ardiç-Mordoğan is later than Paşalar, while the narrowness of the Percrocuta premolars, certainly a primitive feature, would perhaps suggest an age slightly earlier than Çandir. However, some of the features of Protictitherium are definitely more derived at Mordoğan than at Çandir. In spite of these small differences, there is no doubt that the faunal association from Ardiç-Mordoğan is quite similar to those of Paşalar and Çandir, as shown by the values of their similarity or distances indices (comparison with Inönü is impossible because this site has yielded only one carnivore). From 8 to 11 (depending on their precise identifications) of the 11 genera of mammals present at Mordoğan are also present at Çandir, which has 27 genera (GERAADS et al. in press). Eight are present at Paşalar, which has 32 genera. Simpson's index of similarity and Pickford's index of distance are the following:

Paşalar (32) Çandir (27) Mordoğan (11)

Pasalar $\quad 100 / 0$

Çandir $\quad 86 / 4 \quad 100 / 0$

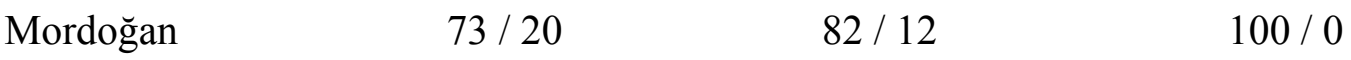

These values, which are consistent with a chronological succession in this order, show that these sites have similar faunal compositions. Therefore, they must belong to the same mammalian biochronological zone, because this is the very definition of a faunal zone. However, since these Turkish sites all belong to different sedimentary basins, and are several hundreds of kilometres apart, it is very unlikely that they are exactly of the same age. It follows that this faunal association probably lasted with little changes for a significant period of time. 
In spite of their similarities, these sites have sometimes been referred to different $\mathrm{MN}$ zones, because of small differences in their faunal compositions, on the basis of comparisons with European sites included in zones MN 5 or MN 6. We believe that this is a wrong argument. Long-distance correlations would require well-dated immigration events, or several shared taxa, but of the species present in Mordoğan, Çandir and Paşalar, which characterize this Middle Miocene Turkish assemblage, only Listriodon splendens is also known in Western Europe, and this is certainly not a sufficient basis for correlation. Thus, we believe that the European biochronological zonation is not applicable to Turkey.

Some comparisons can be made with neighbouring areas. Prebreza in Serbia (PAVLOVIC 1969) has many species in common with Mordoğan, but the Percrocuta differs by its p3, and the proboscidean there is Gomphotherium angustidens, as in Paşalar. It is probably earlier than Mordoğan. Comparison with Kultak (KAYA et al. 2001) is more difficult, because the latter site has yielded mainly Perissodactyls. Belometchetskaya in the North Caucasus (GABUNIA 1973; PICKFORD et al. 2000) has Ischyrictis anatolicus, Percrocuta abessalomi (a species slightly more primitive than P. miocenica), an Amebelodontidae, a Listriodontinae, Kubanochoerus (as at Inönü), Hypsodontus, and perhaps Tethytragus. There are also some differences with Mordoğan. A giraffid p4, although referred to Giraffokeryx by PICKFORD et al. (2000) lacks the vestigial posterior part of the eocristid (Palaeomeryx fold) typical of this genus and Georgiomeryx, and certainly belongs to another taxon. The ungulate fauna is dominated by cervids, as in Europe, and it has no "Hispanotheriinae"; thus, it probably sampled an environment less open than in Turkey. The fauna from Thymiana in Chios, an island just off the Karaburun Peninsula, includes: Lophocyon paraskevaidisi, Sanitherium slangintweiti, Listriodon sp., Hypsodontus cf. gaopense, Tethytragus cf. koehlerae, Dorcatherium sp., aff Euprox furcatus, Georgiomeryx georgalasi, Choerolophodon chioticus, Dinotherium sp. (BONIS et al.1998). All these taxa are different, at least at the specific level, from those present in the previously mentioned faunal group (Tethytragus cf. koehlerae was identified from a fragment of mandible with worn teeth), and Thymiana is certainly earlier. Finally, Inönü (GERAADS et al. 1995; GERAADS in press) looks more recent judging by its bovids, but not by its suids (VAN DER MADE in press), and the position of this site is still controversial.

\section{Acknowledgements}

We thank P. TASSY (Muséum National d'Histoire Naturelle,Paris), and G. SARAÇ (Ankara) for palaeontological and stratigraphic discussions. NESET ÖZTEKIN (Izmir) who recovered the fossils is greatly acknowledged. Thanks also to S. MAYDA (Izmir) for technical 
assistance. This study has been supported by an Aegean University grant (TTM/001/2000), and by the CNRS (programme "Eclipse").

\section{References}

Arambourg, C. 1945. Anancus osiris, un mastodonte nouveau du Pliocène inférieur d'Egypte. - Bulletin de la Société géologique de France, 5 ème sér., 17: 301-310, Paris.

AZAnZA, B. \& MoraleS, J. 1994. Tethytragus nov.gen. et Gentrytragus nov.gen. Deux nouveaux Bovidés (Artiodactyla, Mammalia) du Miocène moyen. Relations phylogénétiques des Bovidés anté-vallésiens. - Proceedings of the Koninklijke Nederlandse Akademie van Wetenschappen, 97 (3): 249-282, Amsterdam.

BESENECKER, H. 1973. Neogen und Quartär der Insel Chios (Ägiäs). - Diss. Freie Univ. Berlin 184: 59.

BLAinVILLE, H. M. D. DE 1841. Ostéographie et description iconographique des Mammifères récents et fossiles (Carnivores). 2, Baillière, Paris.

Bonis, L. De, Koufos, G. D. \& Sen, S. 1997. A Giraffid from the Middle Miocene of the island of Chios, Greece. - Palaeontology 40 (1): 121-133, London.

Bonis, L. DE, Koufos, g. d. \& SEN, S. 1998. Ruminants (Bovidae and Tragulidae) from the middle Miocene (MN5) of the island of Chios, Aegean sea (Greece). - Neues Jahrbuch für Geologie und Paläontologie Abhandlungen, 210 (3): 399-420, Stuttgart.

COlBert, E. H. 1939. A skull and mandible of Giraffokeryx punjabiensis Pilgrim. American Museum Novitates 632: 1-14, New York.

Crusafont-Pairo, M. \& Aguirre, E. 1971. A new species of Percrocuta from the Middle Miocene of Kenya. - Abhandlungen des hessischen Landesamtes für Bodenforschung 60: 51-58, Wiesbaden.

DEPERET, C. 1892. La faune de Mammifères miocènes de la Grive-Saint-Alban (Isère) et de quelques autres localités du bassin du Rhône. - Archives du Muséum d'Histoire Naturelle de Lyon 5 (2): 1-93, Lyon.

Erdogan, B., Altiner, D., GÜNGÖR, T. \& ÖZER, S. 1990. Stratigraphy of Karaburun Peninsula. - Bulletin of the Mineral Research and Exploration 111: 1-20, Ankara. FORTELIUS, M. \& BERNOR, R. 1990. A provisional systematic assessment of the Miocene Suoidea from Pasalar, Turkey. - Journal of Human Evolution 19 (4-5): 509-528, London. 
GABUNIA, L.K. 1973. Fossile Wirbeltiere in der Fauna von Bjelometschesk. Akademie Nauk Grusinsk. SSR. 1-138 (in Russian).

GAZIRY, A. 1976. Jungtertiäre Mastodonten aus Anatolien (Türkei). - Geologisches Jahrbuch, B 22: 1-143, Hannover.

GeraAdS, D., GÜleÇ, E. \& SARAÇ, G. 1995. Middle Miocene Ruminants from Inönü, Central Turkey. - Neues Jahrbuch für Geologie und Paläontologie Monatshefte, 1995 (8): 462-474, Stuttgart.

GERAADS, D. In press. Ruminants, other than Giraffidae. In GÜLEÇ, E., BEGUN, D. \& GeraAds, D. (eds). Geology and Vertebrate Paleontology of the Middle Miocene Hominoid Locality Çandır (Central Anatolia, Turkey). - Courier Forschungsinstitut Senckenberg, Frankfurt.

GERAADS, D. \& ASLAN, F. In press. Giraffidae. In GÜLEÇ, E., BEGUN, D. \& GERAADS, D. (eds). Geology and Vertebrate Paleontology of the Middle Miocene Hominoid Locality Çandır (Central Anatolia, Turkey). - Courier Forschungsinstitut Senckenberg, Frankfurt.

GERAADS, D. \& GÜLEÇ, E. In press. The middle Miocene hominoid site of Çandır, Turkey: Proboscidea. In GÜLEÇ, E., BEGUN, D. \& GERAADS, D. (eds). Geology and Vertebrate Paleontology of the Middle Miocene Hominoid Locality Çandır (Central Anatolia, Turkey). - Courier Forschungsinstitut Senckenberg, Frankfurt.

GeraAds, D., Begun, D. \& GÜLEÇ, E. In press. The middle Miocene hominoid site of Çandır, Turkey: general paleoecological conclusions from the mammalian fauna. In GÜleç, E., Begun, D. \& GeraAds, D. (eds). Geology and Vertebrate Paleontology of the Middle Miocene Hominoid Locality Çandır (Central Anatolia, Turkey). Courier Forschungsinstitut Senckenberg, Frankfurt

HeISSIG, K. 1974. Neue Elasmotheriini (Rhinocerotidae, Mammalia) aus dem Obermiozän Anatoliens. - Mitteilungen der bayerische Staatsammlung für Paläontologie und historische Geologie, 14: 21-35, München.

HelBing, H. 1930. Zur Kenntniss der miocänen 'Mustela' zibethoides Blainville. - Eclogae geologiae Helvetiae, 23 (2): 637-644, Basel.

Howell, F. C. \& Petter, G. 1985. Comparative observations on some middle and upper Miocene hyaenids. Genera: Percrocuta Kretzoi, Allohyaena Kretzoi, Adcrocuta Kretzoi (Mammalia, Carnivora, Hyaenidae). - Géobios, 18 (4): 419-476, Lyon.

KAYA, O. 1981. Miocene reference section for the coastal parts of West Anatolia. Newsletter on Stratigraphy 10 (3): 164-191, Berlin. 
KAYA, T., TunA, V. \& GeraAdS, D. 2001. A new late Orleanian / early Astaracian Mammalian fauna from Kultak (Milas-Muğla), southwestern Turkey. - Géobios 34 (6): 673-680, Lyon.

KRETZOI, M. 1938. Die Raubtiere von Gombaszög nebst einer Übersicht der Gesamtfauna.

- Annales Musei nationalis hungarici 31: 89-157, Budapest.

KÖHLER, M. 1987. Boviden des Türkischen Miozäns (Känozoikum und Braunkohlen der Türkei, 28). - Paleontologia i Evolució 21: 133-247, Sabadell.

LARTET, E. 1851. Notice sur la colline de Sansan. - Annuaire du département du Gers 145.

MeYeR, H. vON 1846. Mitteilungen an Prof. Bronn gerichtet. - Neues Jahrbuch für Mineralogie, Geologie und Paläontologie 1846: 462-476, Stuttgart.

NAGEL, D. In press. Carnivora from the middle Miocene Hominoid locality of Çandır (Turkey). In Güleç, E., Begun, D. \& GeraAds, D. (eds). Geology and Vertebrate Paleontology of the Middle Miocene Hominoid Locality Çandır (Central Anatolia, Turkey). - Courier Forschungsinstitut Senckenberg, Frankfurt.

OzAnsoy, F. 1965. Etude des gisements continentaux et des Mammifères du Cénozoïque de Turquie. Mémoires de la Société géologique de France, N.S. 44 (1): 1-92, Paris. PAVLOVIC, M. 1969. Miocene Mammals from the Toplitska valley. - Annales Géologiques de la Péninsule Balkanique, 34: 269-394 [in Serbian, with German abstract], Beograd.

Pavlovic, M. \& Thenius, E. 1965. Eine neue Hyäne (Carnivora, Mammalia) aus dem Miozän Jugoslawiens und ihre phylogenetische Stellung. - Anzeiger Österreichische Akademie der Wissenschaften, Mathemathischnaturwissenschaftliche Klasse 102 (2): 177-185, Wien.

Pickford, M., Gabunia, L., Mein, P., Morales, J. \& Azanza, B. 2000. The Middle Miocene Mammalian site of Belometchetskaya, North Caucasus: an important biostratigraphic link between Europe and China. - Géobios 33 (2): 257-267, Lyon.

PILGRIM, G. E. 1910. Notices of new mammalian genera and species from the Tertiaries of India. - Records of the geological survey of India 40: 63-71, Calcutta.

PILGRIM, G.E. 1913. The correlation of the Siwaliks with the mammal horizons of Europe. - Records of the geological survey of India 43: 264-326, Calcutta.

Pilgrim, G. E. 1934. Two species of sheep-like Antelope from the Miocene of Mongolia. American Museum Novitates 716: 1-29, New York.

Robertson, A. H. F. \& PicketT E. A. 2000. Palaeozoic-Early Tertiary Tethyan evolution of mélanges, rift and passive margin units in the Karaburun Peninsula (western 
Turkey) and Chios Island (Greece). In Bozkurt, E., Winchester, J. A. \& PiPER, J.

D. A.(eds). Tectonics and Magmatism in Turkey and the surrounding area. -

Geological Society, Special publication 173: 43-82, London.

SCHMIDT-KITTLER, N. 1976. Raubtiere aus dem Jungtertiär Kleinasiens. -

Palaeontographica, A 155: 1-131, Stuttgart.

SoKolov, J. J. 1949. On the remains of Cavicornia (Bovidae, Mammalia) from the middle Miocene of the north Caucasus. - Dokladi Akademie Nauk SSSR, 67: 1101-1104, Moscow.

TAssy, P. 1983. Les Elephantoidea Miocènes du Plateau du Potwar, Groupe de Siwalik, Pakistan. IIe partie: Choerolophodon et Gomphotheres. - Annales de Paléontologie 69 (3): 235-297, Paris.

TASSY, P. 1986. Nouveaux Elephantoidea (Mammalia) dans le Miocène du Kenya. Cahiers de Paléontologie, CNRS, 135 p., Paris

TASSY, P. 1987. A hypothesis on the homology of Proboscidean tusks based on paleontological data. - American Museum Novitates 2895: 1-15, New York.

VAN DER MADE, J. 1996. Listriodontinae (Suidae, Mammalia), their evolution, systematics and distribution in time and space. - Contributions to Tertiary and Quaternary Geology 33 (1-4): 1-254, Leiden.

VAN DER MADE, J. In press. Suoidea (pigs) from the Miocene hominoid locality Çandır in Turkey. In GüleÇ, E., BEgun, D. \& GeraAdS, D. (eds). Geology and Vertebrate Paleontology of the Middle Miocene Hominoid Locality Çandır (Central Anatolia, Turkey). - Courier Forschungsinstitut Senckenberg, Frankfurt.

VIRANTA, S. \& ANDREWS, P. 1995. Carnivore guild structure in the Paşalar Miocene fauna. - Journal of Human Evolution 28 (4): 359-372, London.

Werdelin, L. \& Solounias, N. 1991. The Hyaenidae: taxonomy, systematics and evolution. - Fossils and strata 30: 1-104, Oslo. 


\section{Explanations of figures}

Fig 1. A, Simplified geological map of the Karaburun peninsula. From ERDOĞAN et al. (1990), BESENECKER (1973). B, Simplified stratigraphic column of the Miocene succession in the Karaburun peninsula. From KAYA (1981).

Fig. 2. A-D: Percrocuta miocenica, IMA-3, associated mandible and maxilla. A: lower tooth-row in occlusal view (stereo pair), x 1. B: upper tooth-row (stereo pair), x 1. C: lateral view of the mandible, x 2/3. D: lateral view of the maxilla, x 1. E: cf. Protanancus sp., tip of incisor, IMA-41, x 1. F: cf Protanancus sp., dp4, IMA-51, occlusal view (stereo pair), x 1. G: Hypsodontus pronaticornis, IMA-1, right horn core in front and anterior views, $\mathrm{x} 1 / 2$.

Fig 3. Simpson's diagram of the lengths and widths of Percrocuta lower teeth. Data from Howell \& Petter, 1985; Schmidt-KitTler, 1976; NAgel, in press; Viranta \& ANDREWS, 1995; and unpublished (Inönü).

Fig 4. Protictitherium intermedium paralium n.ssp. Holotype, mandible with p3-m2. A, Lingual view. B, Occlusal view. C, Labial view. Scale $=10 \mathrm{~mm}$.

Fig 5. Scatter plot of length vs. width of Protictitherium m1s. Data from SCHMIDTKiTTLER (1976) and OZANSOY (1965).

Fig 6. Scatter plot of medial height vs. distal width of the Mordoğan Ruminant astragali (black squares) compared with those of Çandir (all others). Çandir data from GERAADS (in press). 